\title{
An assessment of the rate of siltation in Jibia reservoir, Jibia, Katsina state
}

\author{
Y. O. Yusuf \& F. Yusuf \\ Department of Geography, Ahmadu Bello University, Nigeria
}

\begin{abstract}
The Jibia dam was completed in 1991, under the Sokoto Rima River Basin Development Authority (SRRBDA) with support from Katsina state government, with its head work constructed across River Gada for two purposes; water supply and irrigation. The study was conducted at the onset of the rainy season of the year 2011, to determine the current depth of the reservoir, to estimate the rate at which the reservoir is being silted and to examine the factors that gave rise to the level of sediments. The level of sedimentation was determined by measuring the depth of the reservoir from its surface to its bed at different grid points. Finally a contour map was developed using the sediment depth and the coordinates derived using a Global Positioning System (GPS). To compute sediment deposition and the current water holding capacity, average depth was used. The results obtained show that Jibia dam is rapidly silting up with the initial depth of $21 \mathrm{~m}$ reduced to $13.43 \mathrm{~m}$ indicating that $7.57 \mathrm{~m}$ has been lost to sediment accumulation. The reservoir is being silted at the rate of $0.379 \mathrm{~m}$ annually. The Useful life of the reservoir is threatened because $36 \%$ of the storage capacity is already lost leaving $65.95 \%$ storage capacity and by the year 2046, the dam will be completely silted up. This implies that there are serious implications for future water supply in Jibia town and its surrounding villages and conscious efforts have to be made to reduce the siltation rate in order to prolong the useful life of the reservoir.

Keywords: Jibia dam, River Gada, sediments, reservoir depth, siltation rate, contour map.
\end{abstract}




\section{Introduction}

Water being one of the most important natural resources to all living things, brings about the necessity to conserve water and also make it available to man's use in his immediate environment. This leads to construction of dams. A dam is a barrier that impounds water or underground streams that generally serves the primary purpose of retaining water. Dams can be formed by human agency, natural causes or even by intervention of wild life such as beavers. The construction of a dam and the creation of an impounded river reach area usually change the stream natural conditions. Concerning the sedimentological aspect, the dams cause a reduction on the flow velocity, thus causing the gradual deposition of those sediments carried by the stream resulting in the sedimentation, gradually diminishing the reservoir storage capacity. Therefore, it may come to hinder the reservoir operation, besides causing several kinds of environmental problems (Carvalho et al. [1]).

The trap efficiency which is the proportion of a river's total sediment load captured by a dam approaches $100 \%$ for many projects. As the sediments accumulate in the reservoir, the dam gradually loses its ability to store water for the purpose which it was built although the rate of sedimentation depends mainly on the size of the reservoir (Knighton [2]; Strahler and Strahler [3]). A rough estimation by Professor Mahmood of George Washington University for a 1987 World Bank study say that around $50 \mathrm{~km}^{3}$ of sediment capacity is trapped behind the world dams every year (Mahmood [4]). Thousands of small dams constructed by NGO'S and government agencies in 2004 in semi arid regions of east and southern Africa to provide water for livestock and small scale irrigation have lost most of their useful life to excessive siltation.

Siltation problems have been extensively reported around Nigeria which includes Effon Alaye dam in Ondo state which would have completely silted up, but for recurrent dredging. Asejiri dam near Ibadan which had its storage capacity reduced up to $25 \%$ over the years due to intensive cultivation and bush burning in the catchment area (Imevore et al. [5]).

The situation in northern Nigeria is not dissimilar due to the scanty vegetation cover, over cultivation and excessive grazing. This leads to exposure of the soil surface to erosion hence leading to easy transportation of sediments into rivers and silting up of reservoirs as observed in the Daudawa reservoir in Katsina that has completely silted up. Iguisi [6] in his study of the extent of sedimentation in the Kubanni reservoir of Ahmadu Bello University (ABU) observed a loss of about 3.3 metres which represents about 30\% loss in storage capacity in 23 years. The complete siltation of the farm lake and the progressive siltation of the Kubanni reservoir has been a source of worry for the Ahmadu Bello University (ABU Committee [7]; Baba et al. [8]).

\subsection{Research problem}

Jibia dam was constructed for two purposes; water supply and irrigation. The dam is an earth-fill structure with a geomembrane liner, a maximum height of 
$21 \mathrm{~m}$ and an embankment length of $3680 \mathrm{~m}$. The dam had a full storage capacity of $142 \mathrm{Mm}^{3}$ and an active storage capacity of $121 \mathrm{Mm}^{3}$ as at completion and commissioning in February, 1991 under the Sokoto Rima River Basin Development Authority (SRRBDA) with support from Katsina state government. There is a $140 \mathrm{~m}$ long concrete spillway, about $62,500 \mathrm{~m}^{3}$ of mass and reinforced concrete, with discharge capacity of $2170 \mathrm{~m}^{3} / \mathrm{s}$ (Figure 1). The dam and its head work are constructed across Gada River, situated about $2.5 \mathrm{~km}$ south of Jibia dam. The irrigation cum water supply project is a multipurpose project which involves land, water resources and irrigation development to enhance agricultural production in the predominantly farming villages surrounding Jibia.

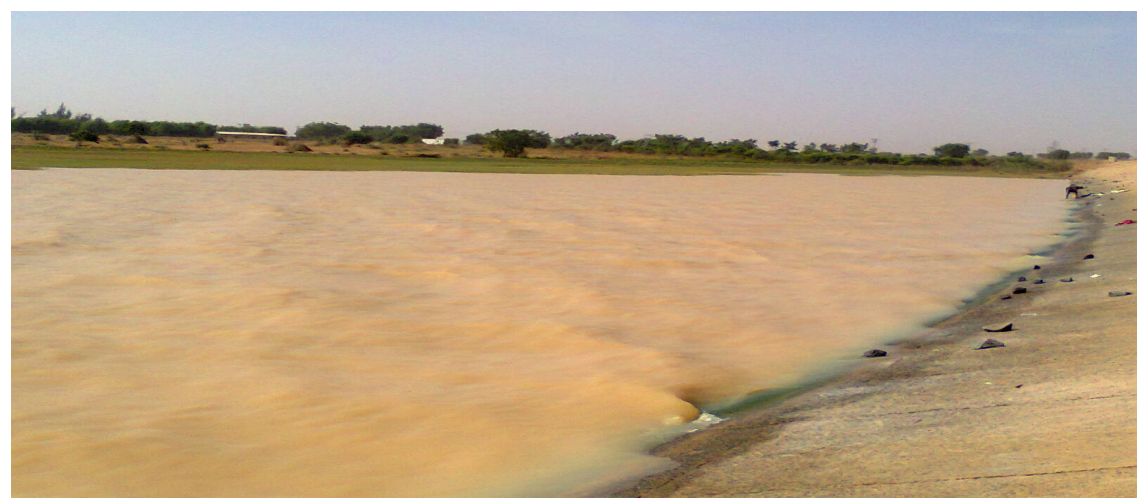

Figure 1: Jibia Dam and its reservoir.

Since the construction of the dam about 20 years ago, there has not been any research carried out to determine its current depth. The dam instruments used for monitoring and maintenance of the dam like daily reservoir level, relief wells level, checking for dislodgements and possible settlement no longer function efficiently. Hence the dam has not been properly monitored and managed (SRRBDA [9]).

The dam has a toe drain which is located at downstream and extends to about $500 \mathrm{~m}$ long. Its function is to collect all the seepage and bottom outlet releases and then discharge it to the main river channel. It also provides pressure relief and guarantee safety, but it is now consequently overgrown with weeds. The water borne environment makes it conducive for giant plants to grow with such an interlocking root system, hence difficult to eliminate or desilt manually. It also creates blockage on seepage lines and all other relief outlets from the dam embankment toe. The gate controls of the compensation reservoirs no longer open or close properly by which designed capacity may no longer be achieved. Erosion is another major issue which has now become gully surrounding the reservoir, also increasing siltation.

In view of all these problems, it is therefore possible that Jibia reservoir may have accumulated silt materials and lost its initial storage capacity. This is why this study becomes imperative and is mainly aimed at assessing the current level 
of sedimentation of the dam, with emphasis on the factors that gave rise to the level and rate of sedimentation of the reservoir.

\subsection{Study area}

Jibia (or Jibiya) town is located about $43 \mathrm{~km}$ west of Katsina town, in Katsina state. The dam and its head work are constructed across Gada River situated about $2.5 \mathrm{~km}$ south of Jibia town. Its coordinates are latitudes $13^{0} 04^{\prime} 18^{\prime \prime} \mathrm{N}$, $13^{0} 10^{\prime} \mathrm{N}$ and longitudes $07^{0} 15^{\prime} 06^{\prime} \mathrm{E}, 07.30^{\prime} \mathrm{E}$ (Figure 2).

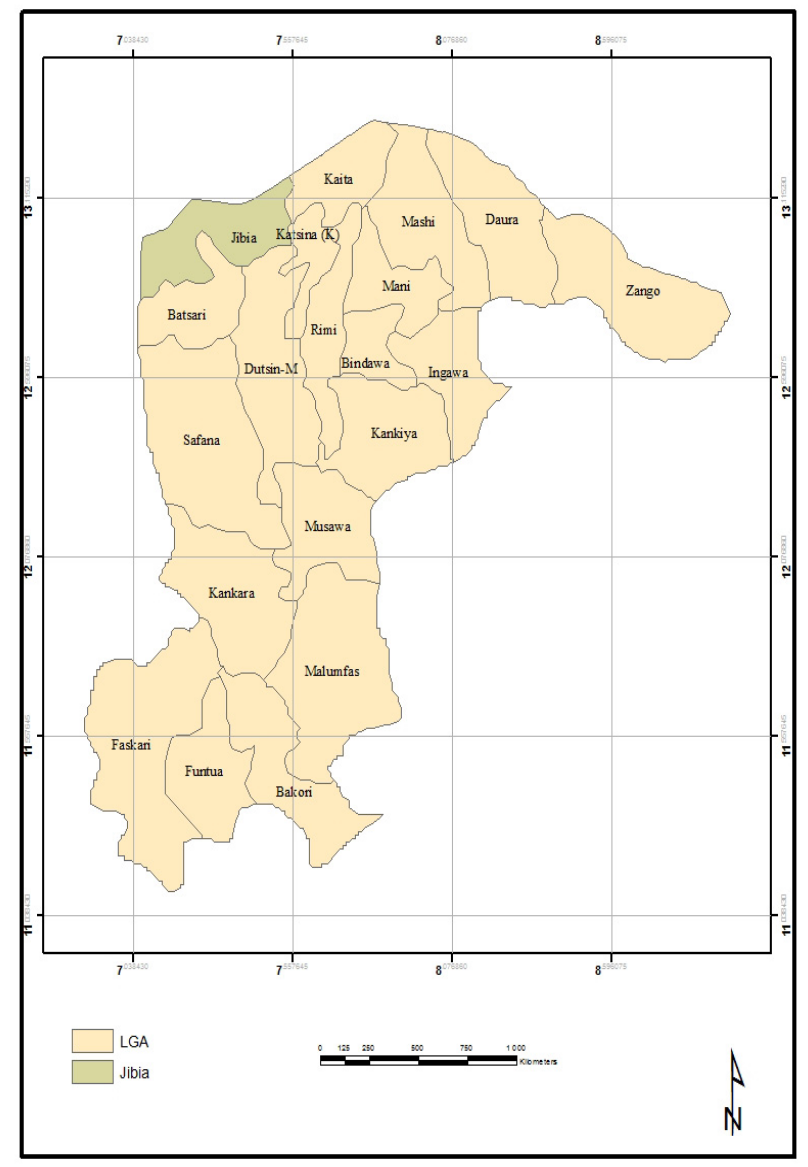

Figure 2: Map of Katsina showing Jibia local government area. Source: Adapted and modified from Katsina state administrative map.

Jibia belongs to the semi arid continental climate which falls within Sudan savannah zone, therefore the climate is largely controlled by two air masses - the tropical maritime air mass and the tropical continental air mass converging at the 
Inter-Tropical Discontinuity (ITD). The gross climatic characteristics of the area are determined by the movement of the ITD which bring about two main seasons which are wet and dry seasons. The mean annual temperature is about $25^{\circ} \mathrm{C}$ while total rainfall figures vary from $600-700 \mathrm{~mm}$ annually.

Types of trees found in the study area include neem tree (Azadiracta indica), acacias (Nilotic albida) and Seya. Shrubs found include Platisma (kalgo) and Cassia singuana (runfu). The grass cover has durable roots which remain underground after stalks are burnt away or wilted in dry season to germinate with the first rains. The existing vegetation in the area is a function of many years of human interference and degradation.

The study area falls within the Chad formation, in this part cretaceous sediment overlap the crystalline rocks. The underlying rocks are overlain by sandy drift deposits laid down during the last arid phase about 12 thousand years ago. The drift deposits are coarse resulting in light sandy soils that are easily worked and well suited to crops such as millet and groundnut.

The local government is traditionally an agricultural area where both rainy and dry season farming is practiced. The industrial potential for agricultural resources include the following; sorghum, groundnut, hides and skins, red sorrel Rumex acetosa [soborodo], acacia Nilotic albida [Bagaruwa] and castor seed (onlinenigeria.com [10, 11]).

\section{Methodology}

There are three main approaches used in estimating sediment yield and these include reservoir/lake sedimentation studies or surveys, fraction collectors or source area measurements of erosion and direct measurements of suspended sediment concentration at basin outlet or sediment sampling (Carvalho et al. [1]; Knighton [2]; Gregory and Walling [12] and Hudson [13]).

This study utilizes the reservoir sedimentation survey technique and the materials used for the data collection include metric tape, canoe, satellite navigator; Global Positioning System, and recording sheets. The measurements of the remaining depth of Jibia dam was done from a canoe. Imaginary grid lines were drawn from the embankment to a significant distance on the reservoir from the north to the south banks. Points of measurements at each intersection of the grid lines were located by a satellite navigator, which was also used to establish the coordinates of each location. The canoe was anchored for the time of depth reading. A measuring tape with a weight tied to its end was deep in into the reservoir, at each sampling point till it reaches the bottom to measure the depth. This procedure was repeated for all the sampling points.

\section{Result and discussions}

\subsection{Result}

The result of the measurements carried out is shown in table 1 , which is presented in three columns, showing the longitude, latitude and the depths in 34 
Table 1: $\quad$ Reservoir depths at different sampling points.

\begin{tabular}{|c|c|c|c|}
\hline S/No. & Latitude N & Longitude E & Depth \\
\hline 1 & N13 $04^{\prime} 18.6^{\prime \prime}$ & E $007^{0} 14^{\prime 23.8}$ & $11.66 \mathrm{~m}$ \\
\hline 2 & $\mathrm{~N} 13^{0} 04^{17.8}$ & E $007^{0} 14^{\prime} 18.0^{\prime \prime}$ & $11.15 \mathrm{~m}$ \\
\hline 3 & N 13 0416.6" & E $007^{0} 14^{\prime} 13.0$ & $10.95 \mathrm{~m}$ \\
\hline 4 & N 13 0416.2" & E $007^{0} 14^{\prime} 07.7^{\prime \prime}$ & $11.30 \mathrm{~m}$ \\
\hline 5 & N $13^{0} 0414.8^{\prime \prime}$ & E $007^{0} 13^{\prime} 59.2^{\prime \prime}$ & $10.80 \mathrm{~m}$ \\
\hline 6 & N $13^{0} 0413.6$ & E $007^{0} 1350.5^{\prime \prime}$ & $10.36 \mathrm{~m}$ \\
\hline 7 & $\mathrm{~N} 13^{0} 04^{\prime} 12.4^{\prime \prime}$ & E $007^{0} 13^{\prime} 43.8^{\prime \prime}$ & $4.40 \mathrm{~m}$ \\
\hline 8 & N1304'11.9" & E $007^{0} 1338.6^{\prime \prime}$ & $7.34 \mathrm{~m}$ \\
\hline 9 & $\mathrm{~N} 13^{0} 04^{\prime} 11.5^{\prime \prime}$ & E $007^{0} 1334.9^{\prime \prime}$ & $5.16 \mathrm{~m}$ \\
\hline 10 & $\mathrm{~N} 13^{0} 04^{\prime} 10.4^{\prime \prime}$ & E $007^{0} 13^{\prime} 29.6^{\prime \prime}$ & $4.18 \mathrm{~m}$ \\
\hline 11 & ${\mathrm{~N} 13^{0} 04^{\prime} 08.7^{\prime \prime}}$ & E $007^{0} 13^{\prime} 20.7^{\prime \prime}$ & $6.85 \mathrm{~m}$ \\
\hline 12 & $\mathrm{~N} 13^{0} 04^{\prime} 07.2^{\prime \prime}$ & E $007^{0} 13^{\prime} 20.0^{\prime \prime}$ & $5.37 \mathrm{~m}$ \\
\hline 13 & $\mathrm{~N} 13^{0} 04^{\prime} 06.6^{\prime \prime}$ & E $007^{0} 13^{\prime} 25.8^{\prime \prime}$ & $6.87 \mathrm{~m}$ \\
\hline 14 & N1304'06.6”' & E $007^{0} 1331.9^{\prime \prime}$ & $8.32 \mathrm{~m}$ \\
\hline 15 & $\mathrm{~N} 13^{0} 04^{\prime} 07.2^{\prime \prime}$ & E $007^{0} 13^{\prime} 37.0^{\prime \prime}$ & $7.77 \mathrm{~m}$ \\
\hline 16 & N1304'07.4" & E $007^{0} 13^{\prime} 41.6^{\prime \prime}$ & $8.18 \mathrm{~m}$ \\
\hline 17 & N13 $04^{\prime} 07.8^{\prime \prime}$ & E $007^{0} 13^{\prime} 47.1^{\prime \prime}$ & $9.52 \mathrm{~m}$ \\
\hline 18 & N13 $04^{\prime} 08.8^{\prime \prime}$ & E $007^{0} 13^{\prime} 51.8^{\prime \prime}$ & $9.67 \mathrm{~m}$ \\
\hline 19 & $\mathrm{~N} 13^{0} 04^{\prime} 08.5^{\prime \prime}$ & E $007^{0} 13^{\prime} 57.7^{\prime \prime}$ & $8.51 \mathrm{~m}$ \\
\hline 20 & $\mathrm{~N} 13^{0} 04^{\prime} 08.7^{\prime \prime}$ & E $007^{0} 14^{\prime} 02.2^{\prime \prime}$ & $9.33 \mathrm{~m}$ \\
\hline 21 & $\mathrm{~N} 13^{0} 04^{\prime} 08.5^{\prime \prime}$ & E $007^{0} 14^{\prime} 09.6^{\prime \prime}$ & $9.87 \mathrm{~m}$ \\
\hline 22 & $\mathrm{~N} 13^{0} 04^{\prime} 07.9^{\prime \prime}$ & E $007^{0} 14^{\prime} 16.0^{\prime \prime}$ & $10.11 \mathrm{~m}$ \\
\hline 23 & N13 $04^{\circ} 03.0^{\prime \prime}$ & E $007^{0} 14^{\prime} 15.0^{\prime \prime}$ & $10.06 \mathrm{~m}$ \\
\hline 24 & N13 $04^{0} 02.9^{\prime \prime}$ & E $007^{0} 14^{\prime} 11.3^{\prime \prime}$ & $9.27 \mathrm{~m}$ \\
\hline 25 & $\mathrm{~N} 13^{0} 04^{\prime} 03.2^{\prime \prime}$ & E $007^{0} 1405.4$ & $4.27 \mathrm{~m}$ \\
\hline 26 & N1304'03.3" & E $007^{0} 13^{\prime} 58.6 "$ & $2.71 \mathrm{~m}$ \\
\hline 27 & $\mathrm{~N} 13^{0} 04^{\prime} 03.2^{\prime \prime}$ & E $007^{0} 13^{\prime} 54.4^{\prime \prime}$ & $4.77 \mathrm{~m}$ \\
\hline 28 & N1304'02.4" & E $007^{0} 1350.1^{\prime \prime}$ & $8.77 \mathrm{~m}$ \\
\hline 29 & N13 $04^{\circ} 01.4^{\prime \prime}$ & E $007^{0} 13^{\prime} 44.3^{\prime \prime}$ & $8.91 \mathrm{~m}$ \\
\hline 30 & N13 $04^{0} 01.4^{\prime \prime}$ & E $007^{0} 13^{\prime 39.5}$ & $5.41 \mathrm{~m}$ \\
\hline 31 & $\mathrm{~N} 13^{0} 04^{\prime} 02.0^{\prime \prime}$ & E $007^{0} 13$ '33.2" & $3.54 \mathrm{~m}$ \\
\hline 32 & $\mathrm{~N} 13^{0} 04^{\prime} 02.5^{\prime \prime}$ & E $007^{0} 13^{\prime} 27.7^{\prime \prime}$ & $4.52 \mathrm{~m}$ \\
\hline 33 & $\mathrm{~N} 13^{0} 04^{\prime} 03.9^{\prime \prime}$ & E $007^{0} 13^{\prime 22.6 "}$ & $3.64 \mathrm{~m}$ \\
\hline 34 & $\mathrm{~N}_{13}{ }^{0} 04^{\prime} 04.0 "$ & E $007^{0} 13^{\prime} 19.1^{\prime \prime}$ & $3.92 \mathrm{~m}$ \\
\hline
\end{tabular}

Source: Field Survey 2011

sampling points in the reservoir where the deepest point is showing depth of $11.66 \mathrm{~m}$ and the lowest point of about $2.71 \mathrm{~m}$. The data on table 1 was used in constructing the contour map of the reservoir depth, showing the depth represented by isobaths and the coordinates as presented in Figure 3.

The contour map shows the isobaths of the reservoir, which exhibits some characteristic features of the reservoir. Each contour line represents the intersection between the reservoir surface and elevation below sea level in latitude and longitude coordinates. The sections containing higher values have steeper slopes showing the deepest points, while the sections containing the lower values have gentle slopes showing the shallow points. 


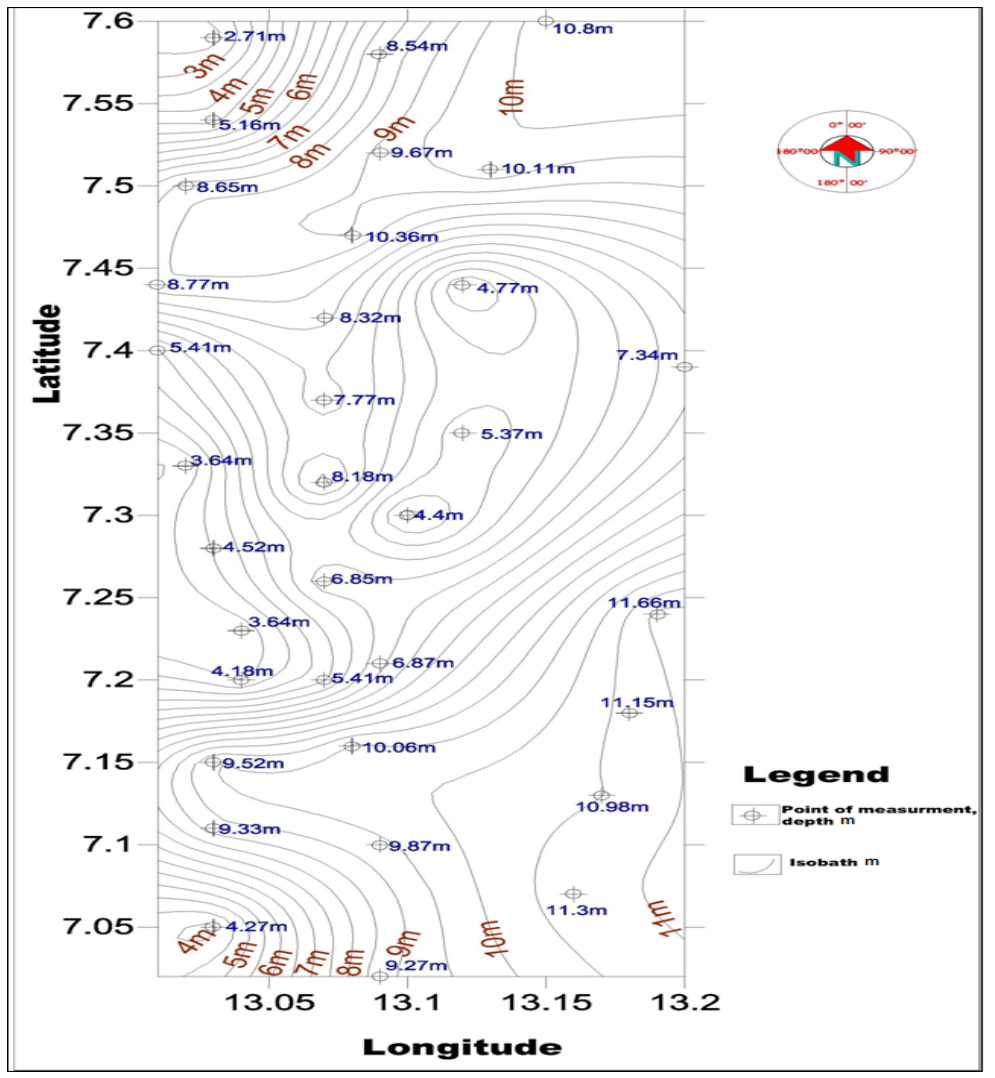

Figure 3: $\quad$ Remaining depth of Jibia impounding reservoir.

\subsection{Discussions}

When the lake was constructed in 1991, its maximum depth was about $21 \mathrm{~m}$. The area of the catchment area was $3666 \mathrm{~km}^{2}$. The result obtained in this study during 2011 onset of the rainy season reflects a maximum and minimum depth of about $11.66 \mathrm{~m}$ and $2.71 \mathrm{~m}$ and an average depth of $7.57 \mathrm{~m}$. This indicates that present water holding capacity is $13.43 \mathrm{~m}$ and $7.57 \mathrm{~m}$ has been lost to sedimentation and this translates into an annual loss of $0.379 \mathrm{~m}$. The data shows that Jibia dam has incurred about 36.05\% storage loss since 1991 (see Figure 4).

The magnitude of loss in the storage capacity of the reservoir and the thickness of the sediment accumulated in 20 years is quite high. The situation of Jibia dam conforms to the issues facing many other small earth dams in East and South Africa, other parts of the country, like Efon Alaye dam in Ondo state, the farm lake and the Kubanni reservoir in Ahmadu Bello University, Zaria. 


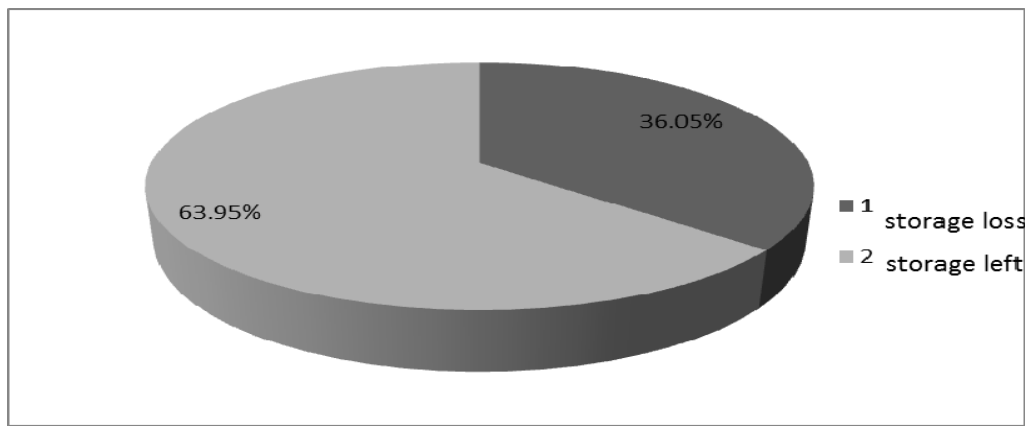

Figure 4: $\quad$ Pie chart showing the storage loss and storage left in Jibia dam.

The operational life of the reservoir is normally determined by the point in time at which sediment accumulations reduce the reservoir yield below supply requirements. This useful life of a reservoir is often defined as the time taken for $90 \%$ live reservoir storage to be depleted, although in practice measures normally have to be taken to ensure reliability of supply. This is dependent not only on the magnitude and the nature of the incoming sediment yield, but also on any physical or operational measures that are in place to reduce the rate at which the remaining storage is depleted.

The susceptibility of a reservoir to sedimentation depends on the sediment delivery, the source water course, the retention characteristics, and the manner in which the flow is delivered from the natural source to the reservoir (Basson and Rooseboom [14]). Jibia dam is susceptible due to problems arising from the above mentioned features of the dam.

A major factor that contributes to the high sediment yield in the Jibia reservoir is soil erosion over the catchment area; the land use in the study area is one of the causes of erosion. Large part of the watershed is under cultivation and often disturbed, and can be easily detached by runoff which is subsequently transported into the reservoir. Farmers were observed ploughing very close to the reservoir peripheries that might contribute much loose soil (easily erodible) that is transported over a shorter distance to reach the reservoir.

Vegetation cover condition in the catchment area of the reservoir appears to be central to all the environmental factors causing high rate of sediment yield. Low rainfall and low soil quality is a major deterrent to a luxurious vegetation in this area, hence making the area more susceptible to erosion which has now become gully surrounding the reservoir due to the fact that there was no protection with either riprap material or stone pitching on the outside walls around.

However, large part of the study area has gentle slopes with few steep slopes found in the watershed peripheries that contribute to a higher run off velocity, leading to deeper gully incisions at the lower slopes.

The fact that this region is characterized by deforestation and soil erosion makes reservoir sedimentation a major threat for the economic life time of the project. Lack of proper implementation of watershed development plans to treat 
major sediment sources by soil and water conservation mechanisms have also accelerated erosion and consequently increased the sediment yield. The dams toe drains as explained in the research problem, whose function is to discharge all bottom outlet releases and seepage into the main river channel, no longer functions properly, hence leading to trapping of sediments in the bottom of the reservoir with no way of releasing them. Due to the nature of soil, which is generally loose and sandy, erosion through run off and wind, make the drains become silted up (see Figures 5 and 6). 50\% or half the design discharge volume is wasted to the siltation. Some areas that are virtually water logged are not even identifiable as they are over grown with giant plants. Others are lost to gully erosion while some were completely flattened or levelled by animal trespasses.

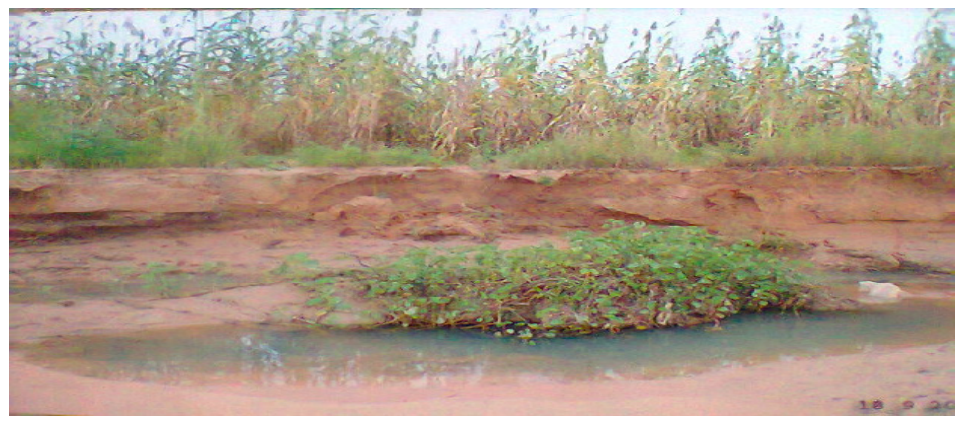

Figure 5: Gully erosion in the Jibia dam’s drainage basin.

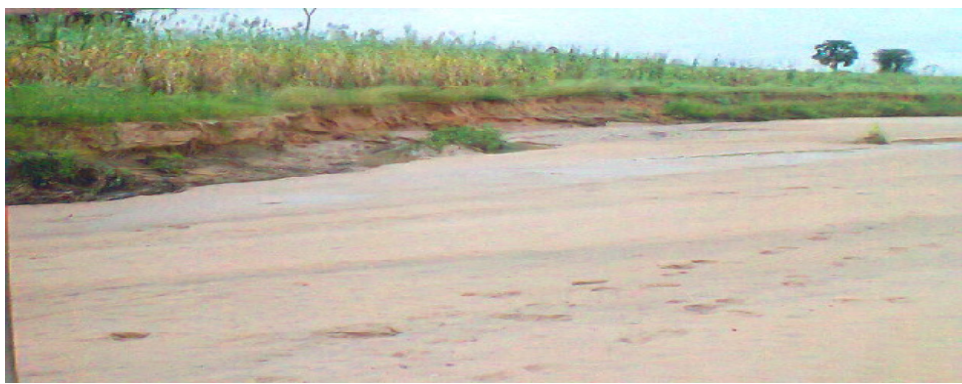

Figure 6: Sediment accumulation in Jibia dam’s drainage basin.

Jibia dam sedimentation when compared with global sedimentation rate is quite in accordance. Basson and Rooseboom [15] stated that although some reservoirs experience problem 10 years after construction, sedimentation becomes a serious problem 50 more years after construction of a dam. With the world wide estimation of $0.8 \%$ average annual sedimentation rate of the original storage capacities, many reservoirs during the next 50 years will be seriously affected by sedimentation.

The Useful life of the reservoir is threatened because $36 \%$ of the storage capacity is already lost. Jibia dam will be completely silted up in the next 35 
years (2046) if no control measures are employed, which is 55 years after construction. With the annual loss of $0.379 \mathrm{~m}$ there is a progressive silting of the reservoir, by which there will be serious water supply problem in the next ten years (2022) and complete siltation in 2046.

\section{Conclusion and recommendations}

\subsection{Conclusion}

From the result obtained and analyzed, it shows that Jibia dam is rapidly silting up. The initial depth was $21 \mathrm{~m}$ and the result shows that presently, $7.57 \mathrm{~m}$ has been lost to sediment accumulation hence leaving $13.43 \mathrm{~m}$ of water holding capacity. The reservoir is being silted at the rate of $0.379 \mathrm{~m}$ annually. This rate of siltation is alarming and calls for immediate action in controlling the sediment yield generation. If the siltation continues at this progressive rate it will result in rationing of water in year 2022 and develop to no water in dry season in starting from year 2032 and a complete siltation in year 2046.

The rate of siltation went unnoticed due to the state of the dam instruments which was initially used in respect to monitoring and maintenance of the dam, like daily reservoir level, relief well levels and function, gauge wells and so on which no longer function properly. Already the community is facing water rationing due to the decrease in the reservoirs carrying capacity and inefficient pumping capacity.

Jibia dam, being the sole source of pipe borne water supply in Jibia town and 20 villages surrounding the town with no other alternative calls for immediate measures to be taken in order to forestall future crises.

\subsection{Recommendations}

In order to prevent and forestall the rate of sedimentation, it is imperative to reduce rate of sediment yield and its entry into this reservoir, the following recommendations should be put into deliberation so as to protract the life of this dam.

The methods for reducing reservoir sedimentation divides into four main options; to minimize sediment loads entering the reservoir, minimize the deposition of sediment within the reservoir basin, remove previously accumulated sediments and replace lost reservoir capacity.

As stated by Mahmood [4] and Rawat [16], intuitively the first method of reducing reservoir siltation would be to reduce sediment yield from the basin upstream by watershed management. This includes afforestation, land use change and construction of micro structures to trap sediments. Sharma [17] also stated that sediment yield could be reduced by $65-94 \%$ through promotion of vegetation instead of bare soil and by $70 \%$ with construction of check dams in the reservoir.

Removal of sediment deposits by dredging or excavation, although it is a costly operation which may be justified in this circumstance by the economic 
value of the water and the impossibility of replacing lost reservoir capacity. The excavated silt should also be disposed properly for the improvement of surrounding agricultural land.

Workers such as Morgan [18] and Yusuf [19] have described approaches to soil conservation based upon agricultural practices and mechanical methods of reducing soil transport. That is; by reducing or banning farming activities and also bush burning, which is a factor causing continuous soil erosion due to the exposure of the soil surface to agents of denudation which contributes heavily to sediment yield around the catchment area.

By relating the complex nature between erosion and sediment yield, it is possible to reduce expenditure by identifying major sediment sources and concentrating soil conservation measures in those areas. Also, the bottom outlets in Jibia dam no longer function properly, but if repaired, flood flushing and venting of turbid currents can prove to be an effective means of reducing deposition in the reservoir, when there's excess of water suitably during the rainy season.

Watershed management is the best way to reduce the yield of sediment and its entry into a reservoir (Bruk [20]). Therefore, a long term monitoring of the reservoir by the SRRBDA on a regular basis is ideal to ascertain the level of siltation. The dam instruments used for monitoring and maintenance of the dam like daily reservoir level, relief wells level, checking for dislodgements and possible settlement should be made to function efficiently. The Katsina state government should also support the SRRBDA strongly in order to achieve this noble aim since their indigenes are the immediate beneficiaries of the project.

\section{References}

[1] Carvalho, O., Junior, N.P.F., Santos, P.M.S. and Lima, J.E.F.W., Reservoir Sedimentation Assessment Guideline. Brasilia, 2000.

[2] Kinghton, D., Fluvial Forms and Processes: A News Perspective. Arnold Publishers, London, 1998.

[3] Strahler, A. and Strahler, A., Introduction Physical Geography. Wiley and Sons, Boston, 2006.

[4] Mahmood, K., Reservoir sedimentation-impact, extent and mitigation, World Bank Technical Paper 71, 1987.

[5] Imevore, A.M., Ogunkoya, O.O., Sagua V.O., Effects of Soil Erosion on Aquatic Ecosystem in Nigeria. Ecological Disasters in Nigeria. Federal ministry of science and technology, Lagos, 1998.

[6] Iguisi, E. O. (1997) An assessment of the current level of sedimentation of the Kubanni dam. Savanna, 18(1), pp. 17-28, 1997.

[7] ABU Committee, Report on results of measurement of the remaining storage in Kubanni impounding reservoir and proposal for upgrading the environment in Kubanni drainage basin. Ahmadu Bello University Committee on the Protection of the Remaining Storage of the Kubanni Reservoir, 2008. 
[8] Baba, A., Akaegbobi, M., Schoeneich, K., Measurement of remaining storage and rate of Siltation of the Ahmadu Bello University Farm Lake at Zaria, Paper presentation at first international inaugural workshop of West African quaternary research Scientists, Ibadan, Nigeria, 2009.

[9] SRRBDA (2000) Jibia irrigation project: Situation report, Sokoto Rima River Basin Development Authority.

[10] Katsina State Physical Setting. www.onlinenigeria.com/links/katsinaadv .asp.

[11] Economic Potentials of Jibia Local Government. www.online.nigeria.com.

[12] Gregory, K.J. and Walling, D.E., Drainage Basin Form and Processes: A Geomorphological Approach, Edward Arnold Publishers Ltd; Pg. 456, 1973.

[13] Hudson, N.W., Field Measurement of soil erosion and runoff, Food and Agricultural Organization Soils Bulletin, 68, Silsoe, Associates, United Kingdom pp. 139, 1993.

[14] Basson, G. R. and Roosboom, A., Dealing with Reservoir Sedimentation: Guidelines and Case Studies. ICOLD bulletin, 115, 1999.

[15] Basson, G. R. and Rooseboom, A. (2007) Mathematical Modeling of Sediment Transport and Deposition in Reservoirs. Bulletin CIGB, ICOLD.

[16] Rawat, M.S. (2011) Environmental Geomorphology and Watershed Management, Concept Publishing Company Pvt. Ltd. New Delhi.

[17] Sharma, K.D., Soil Erosion and Sediment Yield in the Indian Arid Zone. Erosion and Sediment Yield: Global and Regional Perspectives, eds. Walling, D.E. and Webb, B.W. pp. 175-182, 1996.

[18] Morgan, R.P.C., Soil Erosion and Conservation. Second edition, Longman, 1995.

[19] Yusuf, Y.O., Assessment of the Magnitude of sediment produced by the Northern Tributary of the Kubanni River, Unpublished M.Sc. Dissertation. Department of Geography, A.B.U. Zaria, 2006.

[20] Bruk, S., Methods of Computing Sedimentation in Lakes and Reservoirs, IHP - II Project, 1985. 